\title{
OS MITOS DO LAGO FORMOSO EM PENALVA, BAIXADA MARANHENSE: UMA ESTRATÉGIA DE CONSERVAÇÃO QUE DESAPARECE
}

\section{THE MYTHS OF LAKE FORMOSO IN PENALVA, BAIXADA MARANHENSE: A CONSERVATION STRATEGY THAT DISAPPEARS}

\author{
Naila Arraes de Araujo* \\ Oriana Trindade de Almeida** \\ Claudio Urbano Bittencourt Pinheiro*** \\ José Luis Cividanes Hernández ${ }^{* * * *}$
}

\section{Introdução}

Vários estudos têm mostrado como a cultura das populações, em especial as tradicionais, têm resultado em conservação ambiental. De acordo com Mercante (2011), são várias as abordagens sobre este assunto, as quais podem ser agrupadas em duas vertentes: a primeira diz respeito aos estudos onde é dada ênfase acentuada no papel da cultura sobre o comportamento ecológico; a segunda considera o oposto, colocando que o meio ambiente determina a base cultural da sociedade.

Independente da abordagem culturameio ambiente ou meio ambiente-cultura, o importante é que ambas tratam da cultura como eixo para conservação da natureza e, neste sentido, os mitos tornam-se um mediador que tanto influencia a visão da natureza e sua consequente manipulação, quanto podem ser influenciados por essa visão e pela necessidade de manipulação (MERCANTE, 2011). Os mitos influenciam

* É doutora em Ciências Socioambientais pelo Núcleo de Altos Estudos Amazônicos (NAEA/UFPA/Belém/ PA/Brasil) atuando nos seguintes temas: meio ambiente, desenvolvimento sustentável e economia ambiental/ecológica. Atualmente é professora substituta no DEOLI/UFMA. nana.arraes@bol.com.br.

** É doutora em Ciências Socioambientais pela University of London. Atualmente é professora adjunta da UFPA no Núcleo de Altos Estudos Amazônicos (Belém/PA/Brasil). Tem experiência na área de Economia, com ênfase em Economia dos Recursos Naturais, economia dos recursos pesqueiros. oriana@ufpa.br.

*** É doutor em Biologia pela City University of New York. Tem experiência nas áreas de Agronomia e Biologia, com ênfase em Uso, Manejo e Conservação de Recursos Vegetais. Atualmente é Professor Associado da Universidade Federal do Maranhão (São Luís/MA/Brasil). cpinheiro@elo.com.br.

**** É doutor em Economia pela Universidad de Alicante - Espanha. Tem experiência nas áreas de desenvolvimento econômico, cooperação internacional para o desenvolvimento e gestão ambiental. Atualmente é professor titular da Universidade de Alicante no Departamento de Análises Econômicas Aplicadas (Alicante/Espanha).jlcivi@ua.es. 
o comportamento do homem em relação ao ambiente que o cerca, e isto tem importância fundamental quando se trata de controlar o uso dos recursos naturais.

Rappaport (1985) afirma que o homem nasce com capacidade para adquirir cultura, crenças, convencionalismos, conhecimentos e técnicas dependentes da invenção e uso de símbolos. Estes símbolos são sinais relacionados convencionalmente com suas referências e que se podem combinar para formar mensagens complexas. Para este autor, a linguagem é o sistema simbólico fundamental da espécie humana. É por meio dos símbolos que o alcance da comunicação se libera do que é imediato e presente, e por meio deles se pode acumular e transmitir uma enorme quantidade de informação. 0 uso desses símbolos, ou dos mitos, faz parte da cultura de uma civilização, e o conjunto dos mitos, de acordo com Gual et al. (1998), forma a mitologia daquele povo.

Para Hawley (1944), a cultura é um modo de se referir à técnica predominante por meio da qual uma população humana se mantém em seu habitat. Afirma que as partes componentes de uma cultura são idênticas, em princípio, à atração que sente a abelha pelo mel, à atividade das aves para construir ninhos e aos hábitos de caça dos carnívoros. Para Hawley, não importa as diferenças que distinguem a cultura humana, baseada no uso de símbolos, da conduta de animais, mas sim interessa a sua equivalência funcional.

Nesse sentido, Rappaport (1985) afirma que a forma em que o homem participará em qualquer ecossistema depende, não somente da estrutura e composição desse ecossistema, mas também da bagagem cultural de quem entra nele; depende do que os homens e seus descendentes recebam por meio da difusão do que inventam eles mes- mos, das exigências impostas do exterior à população local e das necessidades as quais devem satisfazer a população local com elementos trazidos de fora. Dessa forma, se pode dizer que as culturas se impõem à natureza do mesmo modo que a natureza se impõe sobre as culturas.

0 homem contempla a natureza através de um leque composto de crenças, conhecimentos e propósitos e atua segundo suas imagens culturais da natureza. Sobre isto, Rappaport (1985) comenta a necessidade de se levar em conta o conhecimento e crenças do homem com referência ao mundo que o rodeia, e seus motivos culturalmente definidos para atuar do modo que atuam, caso se deseje compreender suas relações ambientais.

Lévi-Strauss (1984), concordando com White (1959), define a cultura como um conjunto de relações que mantém entre si os fenômenos simbólicos. As culturas humanas estão constituídas de mitos, lendas, crenças e por histórias repletas de símbolos que impactam a imaginação e deixam um rastro fascinante na memória.

Segundo Geertz (2005), nosso bem mais importante é sempre os símbolos da nossa orientação geral na natureza, na sociedade e em tudo que fazemos.

Geertz (2005) engenha as ideias de Kluckhohn, reúne algumas características e expõe claramente a noção de cultura: "o modo de vida de um povo"; "o legado social que um indivíduo adquire de seu grupo"; "uma maneira de pensar, sentir e crer"; "uma abstração da conduta”; "uma teoria do antropólogo sobre a maneira em que se conduz realmente um grupo de pessoas"; "um depósito de saber armazenado"; "uma série de orientações estandardizadas frente a problemas reiterados"; "uma conduta aprendida"; "um mecanismo de regulação normativo da conduta"; "um precipitado de 
história"; "uma série de técnicas para adaptar-se tanto ao ambiente exterior como aos outros homens".

A palavra "mito" provém do termo grego mythos, termo sem equivalente exato em outras línguas antigas e que logo os latinos traduziram por "fábula”. Mythos significava originalmente (por exemplo, nos textos homéricos) "palavra, discurso, relato, narração, fábula, conto”, com um sentido amplo que tinha seu uso concretizado dependente do contexto.

Ainda hoje, o mito é um fenômeno de muitas definições. Ele faz parte de um conjunto de fenômenos de sentido difuso, pouco claro. Significa muitas coisas, representa várias ideias e serve para ser usado em diversas situações.

0 mito também é definido por Gual et al. (1998) como uma narração dramática e de origem tradicional que conta a atuação decisiva e memorial de personagens extraordinários. A narração mítica vem assim explicar, de um modo imaginário e simbólico, com força dramática e simples, aspectos importantes do mundo social. Pertence à memória coletiva de um povo e se conta de geração a geração, como uma herança cultural decisiva para compreender e ordenar o mundo e as instituições básicas da sociedade.

Para Barthes (2000), o mito é uma fala, uma linguagem que necessita condições particulares, como a transferência de histórias de geração em geração, para se converter em mito; constitui um sistema de comunicação, uma mensagem. É um sistema semiológico. Para este autor o mito não pode ser um objeto, um conceito ou uma ideia; trata-se de um modo de significação, de uma forma. Tudo pode se tornar um mito, pois o universo é infınitamente sugestivo; cada objeto do mundo pode sair de uma existência fechada e mudar a um estado oral, aberto à apropriação da sociedade, pois nenhuma lei, natural ou não, nos impede de narrar sobre coisas.

Foram muitas as tentativas teóricas para entender o que significa mito. Claude Lévi -Strauss, Michel Foucault e Sigmund Freud, entre outros, são os clássicos do saber ocidental e tiveram uma importante contribuição para interpretação do mito. Para Lévi -Strauss existe uma relação muito próxima entre mito e linguagem, o mito provém do discurso se tornando conhecido.

Rocha (1985) menciona que o mito se deixa eternamente interpretar, e esta interpretação torna-se, ela mesma, um novo mito. Em outras palavras, as interpretações não esgotam o mito. Pelo contrário, a ele se agregam como novas formas de o mito expor suas mensagens. Destaca ainda que o mito está na vida social, na existência, e que sua "verdade", consequentemente, deve ser procurada em outro nível, numa nova lógica. 0 que subsiste de comum nos muitos e alternativos discursos sobre o mito é a ideia constante de que o mito está, efetivamente, ligado à possibilidade de ser interpretado.

Embora o mito possa não ser a verdade, isto não quer dizer que seja sem valor. A efıcácia do mito, e não a verdade, é que deve ser o critério para pensá-lo. 0 mito pode ser efetivo e, portanto, verdadeiro como estímulo forte para conduzir tanto o pensamento quanto o comportamento do ser humano ao lidar com realidades existenciais importantes. Em última instância, a própria ideia de verdade é um conceito discutível. Muitos pensadores acreditam que ela não exista e que o que chamamos verdade não passe, no fundo, de uma versão bem-sucedida sobre um determinado acontecimento. Nesse sentido, procurar saber se o mito diz estritamente a verdade 
torna-se uma tarefa, na melhor das hipóteses, inútil (ROCHA, 1985).

Ainda hoje se discute o significado e objetivo do mito. Mas a ideia principal, quando tratamos de mito nesta seção, é a de que o mito serve como fator de influência para o comportamento humano; este, guiado pela imaginação, pelo imaginário e pelo simbólico, o que tem influência direta sobre a conservação da natureza quando o homem está em contato direto com o meio ambiente que o cerca. A ideia é de que o mito está na raiz das culturas e tem grande importância, pois consegue modificar e controlar, inconscientemente, o modo como as populações, em geral, agem. Mas o mito também desaparece, ou existe e deixa de ser acreditado pelas populações.

Neste sentido, Rappaport (1985) questiona se a conduta empreendida com respeito às convenções sociais, econômicas, políticas ou religiosas contribuem para sobrevivência e bem estar das pessoas ou, pelo contrário, as ameaça, e se esta conduta mantém ou degrada os sistemas ecológicos nos quais vivem as pessoas. Perguntas culturais são assim respondidas tendo em conta os efeitos da conduta culturalmente informada sobre a natureza. 0 autor afirma ainda que adaptações culturais, como todas as adaptações, podem ter e geralmente têm ao longo das mudanças, resultados contraproducentes ao diminuir em vez de aumentar as possibilidades de sobrevivência dos organismos, ou seja, de conservação da natureza.

Diegues (2008) relata que na concepção mítica das sociedades primitivas e tradicionais existe uma simbiose entre o homem e a natureza, tanto no campo das atividades do fazer, das técnicas e da produção, quanto no campo simbólico. Essa unidade é ainda mais evidente nas sociedades indígenas brasileiras, por exemplo, onde o tempo para pescar, caçar e plantar é marcado por mitos ancestrais, pelo aparecimento de constelações estrelares no céu, por proibições e interdições. Mas ela também aparece em culturas como a caiçara do litoral sul e ribeirinhos amazonenses, de forma menos clara talvez, mas nem por isso menos importante.

Nesse sentido, o manejo desses recursos está diretamente ligado com mitos, regras, valores e conhecimentos que definem o período e a maneira como tais recursos serão utilizados, podendo ser considerados “elementos culturais regulatórios”, pois determinam as atitudes das pessoas perante o meio ambiente (CULTIMAR, 2008 apud PEREIRA e DIEGUES, 2010).

\section{Valor cultural dos aterrados e sua relação com a conservação da natureza}

O Formoso é um dos mais importantes lagos da região da Baixada Maranhense, particularmente da região lacustre de Penalva. Como sugerido pelo seu próprio nome, é um bonito lago de águas escuras, localizado a, aproximadamente, $27 \mathrm{~km}$ de distância da sede do município de Penalva, por via aquática. Segundo a gente local do povoado de Caetetú - à margem do Formoso - o lago é protegido por entidades espirituais, chamadas de Encantados, e que vivem em suas ilhas flutuantes (Figura 1). 


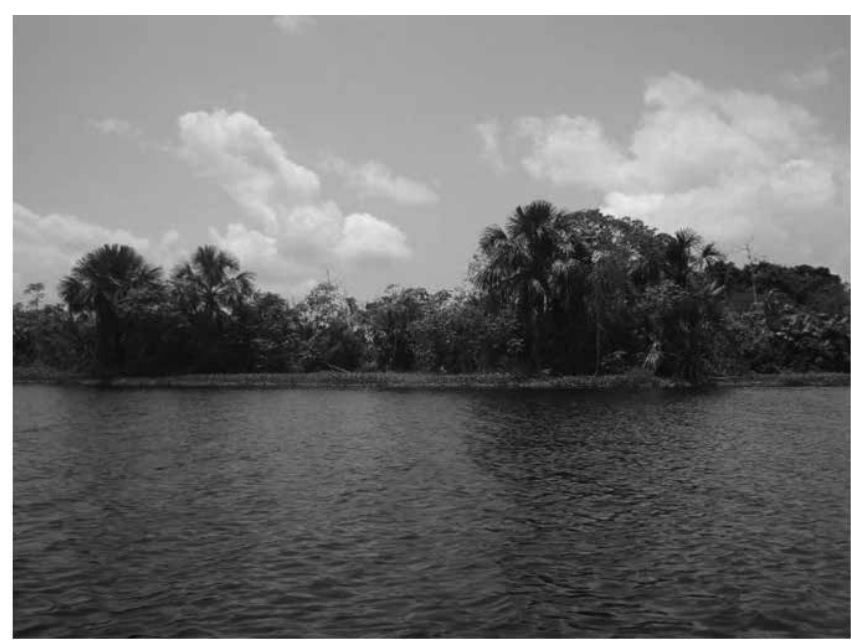

Foto: Naíla Arraes (2011)

Durante a estação chuvosa (janeiro a junho), depois da subida das águas, as ilhas do lago Formoso iniciam uma interessante dança. "Empurradas pelos Encantados", as ilhas flutuam, movendo-se insistentemente pelo lago, a favor e, mais surpreendentemente, contra os ventos, reforçando a crença local na presença dos Encantados e em seu papel no movimento das ilhas. Os choques constantes das ilhas contra as áreas de entorno do lago produzem grande barulho, o que alimenta o imaginário popular dos ribeirinhos do Formoso.

No imaginário popular local, as ilhas têm a proteção dos Encantados; danificá-las pode implicar em pesados castigos contra os malfeitores - como perdas de apetrechos de pesca, visões assustadoras, doenças, morte, entre outros. Por muito tempo, a crença nos seres sobrenaturais contribuiu para a conservação dos Aterrados. Contudo, as crenças vêm perdendo força e, com isto, o temor dá lugar ao uso intensivo, gerando risco crescente para os Aterrados ${ }^{1}$, em seu fraco equilíbrio com o lago Formoso.

Levantar e entender esta relação de cultura com a conservação ambiental pode ser importante para o seu resgate como mecanismo de controle ou redução das perdas ambientais que acontecem na atualidade.

No início da década de 1980, Strauss já chamava atenção para a necessidade de estudos urgentes sobre a cultura das populações: "Se deve acelerar as inves-

1. Os Aterrados são o principal e mais singular ecossistema ambiental da área lacustre. Caracterizam-se por um tipo de vegetação particular de áreas de águas quase paradas e pantanosas. Nestes ambientes, o substrato que sustenta as matas é resultado do continuado acúmulo de matéria orgânica sem conteúdo significante de frações e minerais (Histosolos). São substratos tipicamente úmidos com lençol freático alto e camada orgânica de $40 \mathrm{~cm}$ a 2 metros de espessura. Neste tipo de vegetação se desenvolvem palmeiras como Buriti (Mauritia flexuosa L.) e Juçara (Euterpe edulis Martius), além de uma grande variedade de espécies arbóreas e não tem similares fora dos Aterrados. 
tigações, aproveitar os últimos anos que restam para recolher informações, compensar a diminuição dos grupos e a extinção dos costumes criando métodos de observação cada vez mais precisos; e por fim manter a confiança no provir da etnologia tradicional que, ainda depois da extinção da última tribo "primitiva", deverá prosseguir, durante séculos, sem dúvida, a exploração da enorme quantidade de materiais que foi acumulado." (STRAUSS, 1984, p.18).

Nesse sentido, além de registrar a cultura relacionada aos Encantados e sua relação com a conservação da natureza, apontamos as narrativas orais escutadas.

\section{Metodologia}

Para entender o valor cultural dos Aterrados, seus mitos e a relação destes com a conservação, foi utilizado um roteiro para realização de entrevistas com informantes capazes de responder às questões sobre a cultura local, entre outras perguntas que contribuíram para o entendimento da importância da manutenção do mito para conservação da natureza.

As entrevistas foram feitas seguindo a técnica da Bola de Neve (AMOROZO, M. C. M; MING, L. C.; Da SILVA, S. P., 2002), na qual informantes de reconhecido conhecimento sobre a cultura local respondem às perguntas e indicam, ao final da entrevista, outra pessoa de grande saber sobre o tema pesquisado. Foram realizadas oito entrevistas, algumas por meio de filmagens. Durante as entrevistas houve conversas informais com pessoas mais jovens para saber se acreditam ou não nos mitos.

Nesse sentido, através de análise dos contos orais e narrativas buscamos compreender como o imaginário mítico local influencia (va) no comportamento do indi- víduo para a conservação da natureza e por que estes mitos vêm se perdendo.

\section{Os mitos levantados da região do lago Formoso}

Na região do lago Formoso, três mitos são conhecidos: o mito dos Poraquês, o mito da Aningueira e o mito dos Encantados, este último permeia todos os acontecimentos miraculosos vividos por alguns moradores.

\subsection{Mito dos Poraquês}

Figura 2 - Representação do mito dos Poraquês

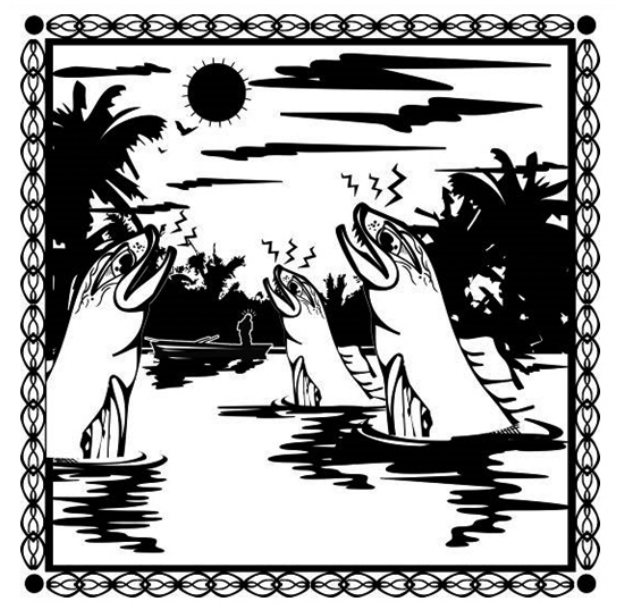

Fonte: elaboração própria

0 imaginário local atribui aos Poraquês a missão de guardiões da porta do Lago Formoso, por determinação dos Encantados. Esses peixes elétricos se concentram na entrada do canal do lago. A razão disso é a grande concentração de piabas na área que servem de alimento a esses peixes. 


\subsection{Mito da Aningueira}

Figura 3 - Representação do mito da Aningueira

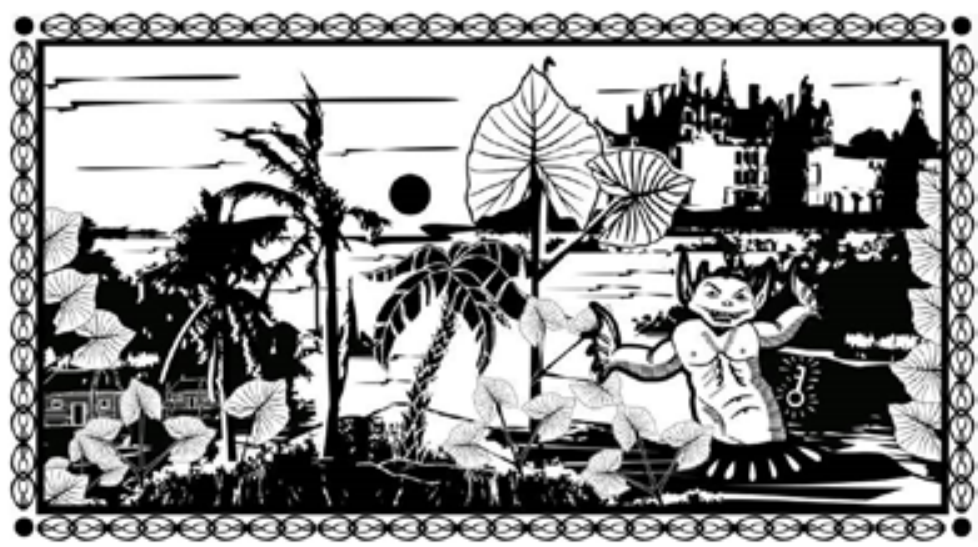

Fonte: elaboração própria

Grande extensão dos campos do Formoso é coberta de Aterrados com aninga gigante. São tantas aningueiras que é possível encontrá-las nos dois tipos de Aterrados, no fixo e no flutuante. A lenda da Aningueira existe há muito tempo. $\mathrm{Na}$ época do surgimento do mito existia uma só ilha flutuante, tão grande que chegava atravessar no meio do lago e a interromper a navegabilidade das embarcações. Criouse uma história de que no meio dessa ilha existia uma Aningueira Gigante, que era a chave de uma cidade encantada que existia há milhares de anos, fundada por um bruxo, que havia se transformado em um monstro chamado de "Come no Fundo". Ele sempre aparecia para as pessoas que habitavam nessa cidade encantada mostrando apenas a metade do corpo para cima. A lenda dizia que se uma pessoa conseguisse achar essa Aningueira e a cortasse em uma só vez teria uma grande surpresa: os encantos se desfariam, o lago se transformaria nessa linda cidade e parte da terra firme viraria lago. Mas ninguém teve cora- gem de procurar essa Aningueira até hoje. Este mito foi contado por muitas gerações e ainda existem pessoas que não querem se aproximar das ilhas com medo de ver o "Come no Fundo".

Em uma das entrevistas, a história da Aningueira é narrada, mas sem a citação do "Come no Fundo": "Olha, dizem que se uma pessoa cortar uma aningueira gigante com um só talho, o lago vira uma cidade muito bonita e pro lado daqui (terra firme) só pode virar outra coisa.” (Dona Benedita).

Em outra entrevista, o Come no Fundo é citado, porém sem comentários sobre a Aningueira, como mostra parte de relato de "Seu” Raimundo dos Santos: "Dona, uma vez, de dia, eu vi um bicho muito grande! Era um bicho de cabelo, peludo, que se ergueu na água. Ele subiu e desceu que a água escumou (sic). Ele tava assim como uma distância longe. Era um bicho enorme. Saiu na água e apareceu da cintura pra cima. Daí, eu chamei meu companheiro de pescaria pra gente ir embora. Será que não era o Come no Fundo? Eu pensei que era ele. Mas, era 
um bicho muito bruto. E muita gente já viu ele. Mas, eu acho que ele não tá mais aqui... foi embora aí pras bandas de Penalva. Não tá aqui mais no Formoso não. Ele é tipo um pau vergado. Tem as costas da largura de uma canoa. A gente não olha nem a cabeça dele e nem o rabo. Só o seio dele. E aquilo no fundo da água faz chuá, chuá... Quando eu olhei, parece que eu não tinha um fio na cabeça. Fiquei todo arrepiado. Então, eu vim remando a canoa até a beira com meu companheiro... chegamos no porto e pulamos da canoa porque o bicho vinha perseguindo."

"Seu" Euzébio conta também que viveu a mesma história:

“Olha, eu já vi um bicho da costa larga. Mas, não se olhava nem a cabeça e nem o rabo. Quando ele passou na minha frente ficou só o escumeiro (espuma)... nesse tempo o lago era muito fundo. Eu ficava com muito medo."
Outro entrevistado relata também ter visto a mesma coisa: "Um dia eu tava pescando com meu sobrinho e nós dois vimos o Come no Fundo. Na mesma hora a gente veio embora. Senhora, o bicho era tão feio que meu cabelo arrepiou. Eu é que não me banho num lago desse. Outro dia um velho foi banhar no porto e o bicho veio. Pra senhora ver como foi verdade que, quando o bicho veio, os peixes pularam no seco que o povo pegou peixe com a mão.” (Eldeson)

\subsection{O Mito dos Encantados}

Em várias narrativas orais a responsabilidade dos fenômenos sobrenaturais é atribuída aos Encantados, como comprovam as histórias contadas abaixo.

\subsubsection{História dos passos que seguiam um pes-} cador

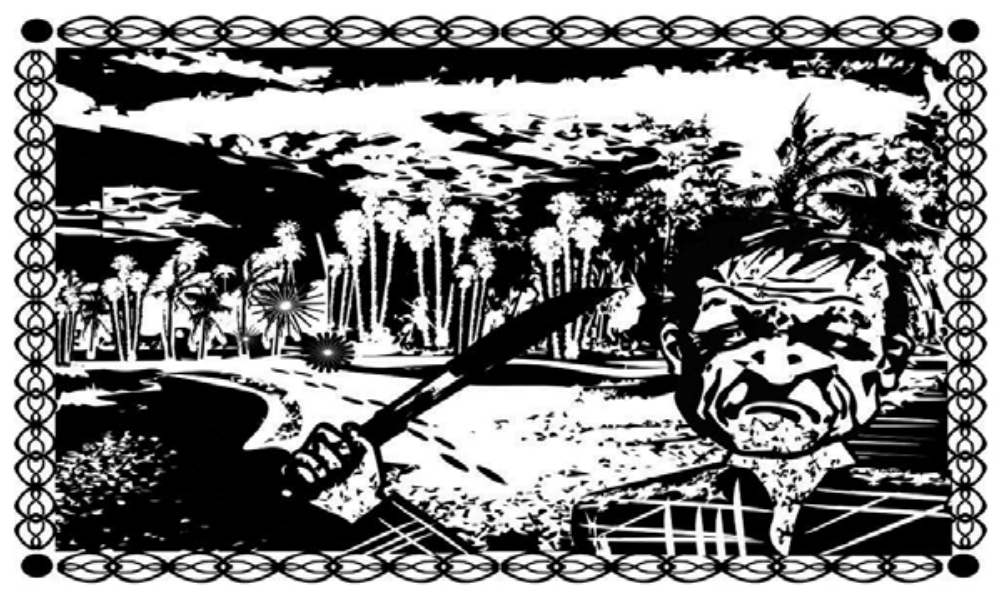

Fonte: elaboração própria 
Vivia na região do Formoso um velho agricultor que passou grande parte de sua vida trabalhando na roça para criar seus filhos. Quando chegava o período de inverno ele sempre saía à noite para pescar de facho (uma lamparina em um pedaço de madeira e amparo de bainha de babaçu). Sozinho, ia pela margem do lago repleta de Aterrados fazendo um longo percurso que durava muitas horas. Certa vez, o velho começou a ouvir passos que lhe seguiam. Ele parava e os passos também. Toda vez que chegava à casa de volta da pescaria dizia para sua esposa: "Muié, eu vou largar de pescar sozinho nesses campos". Mas, não explicava o porquê. No entanto, a necessidade o obrigava a novas aventuras. Toda vez que ia pescar acontecia a mesma coisa. E os passos que ele ouvia pareciam se aproximar cada vez mais. A sua coragem era confiada apenas nos instrumentos de pesca: um facho que dava para iluminar apenas uns três metros ao seu redor e um facão. Essas eram as armas que confiava para enfrentar qualquer perigo. Em uma dessas aventuras o fenômeno sobrenatural veio com mais intensidade, os passos se tornaram mais frequentes. Em uma noite foram tão fortes que ele não resistiu de tanto medo. Saiu desorientado, correndo, e atrás dele se ouvia o correr dos passos. Sentia um arrepio em seu corpo todo, dos pés a cabeça. Quando chegou a casa, muito cansado de tanto correr e aos gritos, mandou que fechassem as portas e janelas porque havia algo estranho atrás dele. A sua esposa e os filhos saíram para ver o que estava acontecendo e nada viram. Desse dia em diante nunca mais foi pescar sozinho.

\subsubsection{História do pescador de traíra}

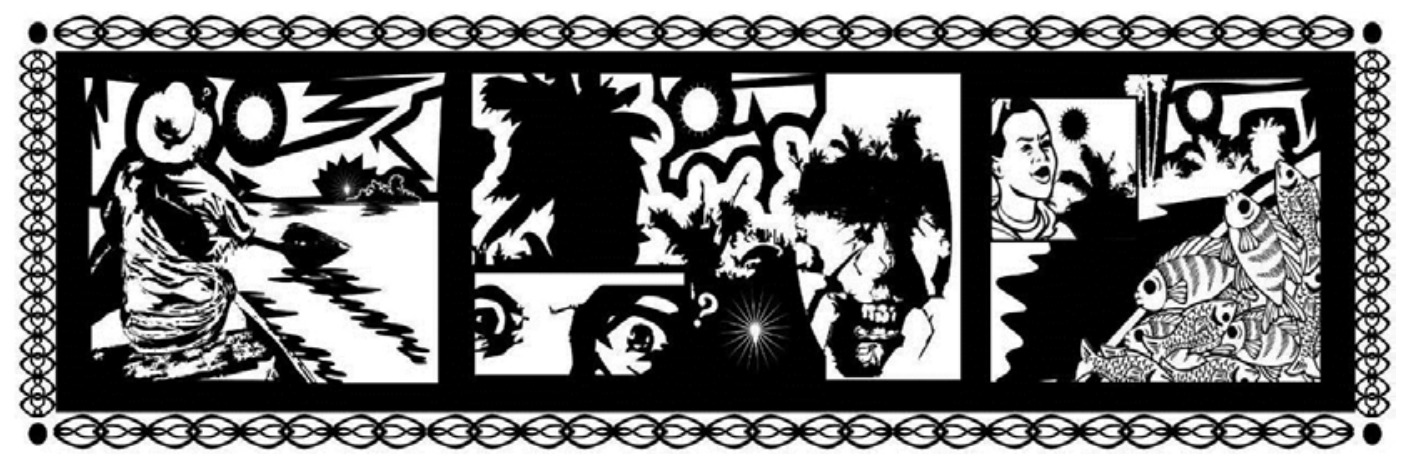

Fonte: elaboração própria

Contam que havia na região um antigo agricultor conhecido de todos. E como todo bom homem do campo, de tudo ele sabia um pouco. Era seu costume sair aos finais de semana para pescar o peixe da sema- na para que assim pudesse trabalhar só na roça. Em um belo dia de sol ardente, resolveu fazer uma pescaria de anzol no Lago Formoso. 0 agricultor, com seus longos caniços de pau, embarcou em uma canoa e 
seguiu para a pescaria. Pegou as iscas (piabas), remou quase o lago todo e não fisgou nenhum peixe. Desesperado, aproximou-se de uma ilha encantada (flutuante), sentouse dentro da canoa, a uns vinte metros de distancia da ilha, debaixo da sombra de um buritizeiro. Depois de um tempo fez novas tentativas de pesca e nada adiantou. Recolheu os anzóis, colocou-os ao seu lado na canoa, picou um fumo e fez um cigarro. Começou a fumar e pensar que não poderia chegar à sua casa, sem peixe. Preocupado, olhava de um lado para o outro, pois isso nunca tinha lhe acontecido. De repente, uma minúscula luz apareceu na borda da canoa e começou a subir passando pela sua perna em direção do seu rosto e, quando ele prestava atenção para ver de onde vinha, ela desaparecia. Até que descobriu que a luz vinha da ilha encantada. Já chateado por não ter pescado nenhum peixe, irritou- se mais ainda, pois achou que alguém da ilha lhe provocava. Não pensou duas vezes, e indignado remou na direção da ilha. Ao chegar perto, pegou o facão, subiu na ilha xingando e procurou a luz ao seu redor, mas nada viu. Como nada encontrou, resolveu ficar mais um pouco sentado por ali. Depois de um bom tempo sentado e triste, resolveu pedir desculpas pela sua ira e por não pedir licença para entrar na ilha. Pediu para a ilha e seus Encantados que o fizessem pegar alguns peixes em quantidade suficiente para fazer pelo menos a refeição do dia. Bastou ele embarcar, mudar de lugar e colocar o anzol na água. Uma hora de pescaria foi o suficiente para o seu desejo. Pegou tanto peixe (traíras) que não acreditou no que estava acontecendo.

3.3.3. História de uma ilha que causou a morte de um morador

Figura 6 - Representação da história da ilha que causou a morte de um morador

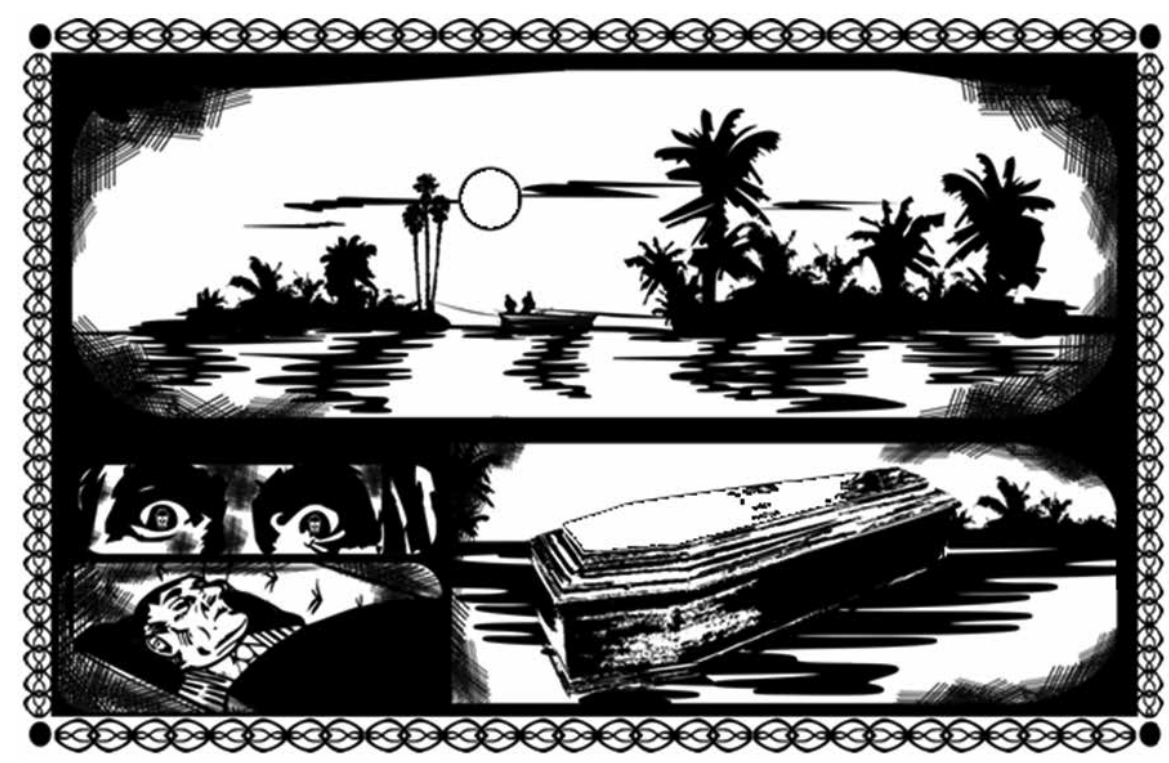

Fonte: elaboração própria 
Em um pequeno povoado na região do Formoso, um pescador se indignou com a perda de sua rede. No lago, as ilhas flutuam no fim do inverno e causam prejuízo aos pescadores, pois estes colocam suas redes e as ilhas passam por cima rasgando e levando as redes embora. Esse pescador já tinha passado por isso várias vezes. Colocava a rede e a ilha vinha e tirava. Certo dia, ele pensou em uma estratégia para evitar o "problema". Achou que ia ser bom para todos os pescadores. Então convidou um amigo e resolveu amarrar com cipós a pequena ilha. Embarcaram em uma canoa e foram ao encontro da ilha que rasgava e levava embora suas redes. Quando a encontraram, o pescador foi se aproximando da ilha e xingando. Xingou tanto que seu amigo reclamou. 0 pescador amarrou o cipó em uma árvore que estava na ilha e em outra que estava em outro Aterrado na beira do lago. Depois disso ele foi embora muito feliz dizendo que a ilha nunca mais rasgaria suas redes. Não rasgaria mesmo, pois logo ao chegar à sua casa ele sentiu uma dor de cabeça muito forte e no outro dia faleceu. Segundo os moradores da re- gião, foram os Encantados que o castigaram pelos xingamentos e por ter amarrado a ilha.

Histórias parecidas também são contadas. "Dona” Maria Antonia, moradora do povoado Caetetú, afirma que aconteceu fato parecido, pois ela viu a pessoa que foi castigada por um Encantado, como mostra parte do seu relato:

"Tinha um senhor que morava aqui, chamado Pedro Pinheiro. Ele tocou fogo em uma ilha só porque ela sentou em cima da rede dele. Mas, a ilha não queimou toda. Queimou só um pouquinho. Quando ele chegou em casa, tava com o braço esquerdo duro porque ele agarrou uma aningueira e cortou com o facão. Alguns dias depois, o outro braço ficou duro. Quando deu oito dias, o homem tava baldeando (vomitando) uma porção de bicho (vermes). Não teve curandeiro para botar ele bom. Isso só se a ilha resolvesse curar ele. Dessa vez ele morreu. 0 homem ficou fininho porque ele não conseguia comer. Até água ele baldeava. Ele era negro e morreu branquinho." 
Figura 7 - Representação da história da tarrafa que foi cortada

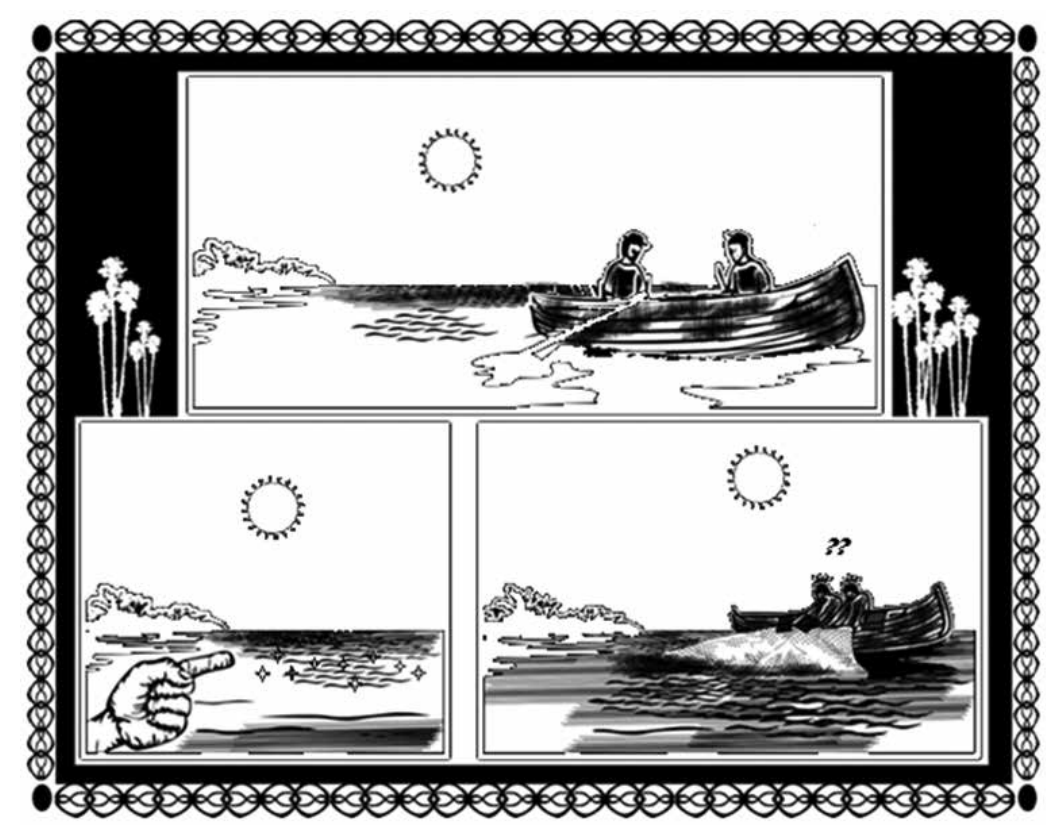

Fonte: elaboração própria

A história diz que um pescador recém chegado ao lago Formoso perdeu sua tarrafa por não ouvir, à época, os mitos contados pelos moradores mais antigos. De acordo com eles, existiam lugares e horas determinadas para pescar, e que antes de pescar era preciso sinalizar alguns gestos de respeito para com as ilhas e com os Encantados. Era preciso pedir licença em voz alta, levar pequena quantidade de fumo e/ ou cachaça e deixá-la nas ilhas flutuantes. 0 novo pescador era daqueles que não acreditava em magia ou em espíritos encantados, como acreditavam os moradores daquela época. Então, em um belo dia, o novato arrumou sua tarrafa e outros instrumentos de pesca e convidou um companheiro para ir pescar. Iniciaram a pescaria, tarrafeando de lado para o outro e não en- contraram peixes. Passaram horas no lago e nada pescaram. Já cansados, os dois pararam um pouco e ficaram pensando no que estaria acontecendo. De repente, ao longe, avistaram espelhos de água feitos pelo sol e o novato disse que, com certeza, era sinal de muitos peixes naquela parte do lago. Os dois remaram em direção ao espelho de água, e ao chegarem o novo pescador se preparou e tarrafeou. Quando a tarrafa chegou ao fundo do lago ele sentiu que estava cheia de peixes, pois a tarrafa pesou. Os dois pescadores estavam numa alegria só. A tarrafeada traria muitos peixes que compensaria todas as horas que ficaram no lago sem pescar nada. Para a surpresa deles, quando começaram a puxar a tarrafa não sentiram mais peso nela e puxaram de uma vez. 0 susto foi ainda maior, porque a 
malha da tarrafa saiu da água e a chumbada ficou no fundo como se alguém tivesse cortado toda a borda da tarrafa retirando todos os chumbos, sem restar um só. Os dois ficaram entre olhares, foram embora e nunca mais voltaram ao Lago Formoso. Os Encantados os castigaram por não terem pedido licença para pescar.

\subsubsection{História de uma luz misteriosa}

Figura 8 - Representação da história de uma luz misteriosa

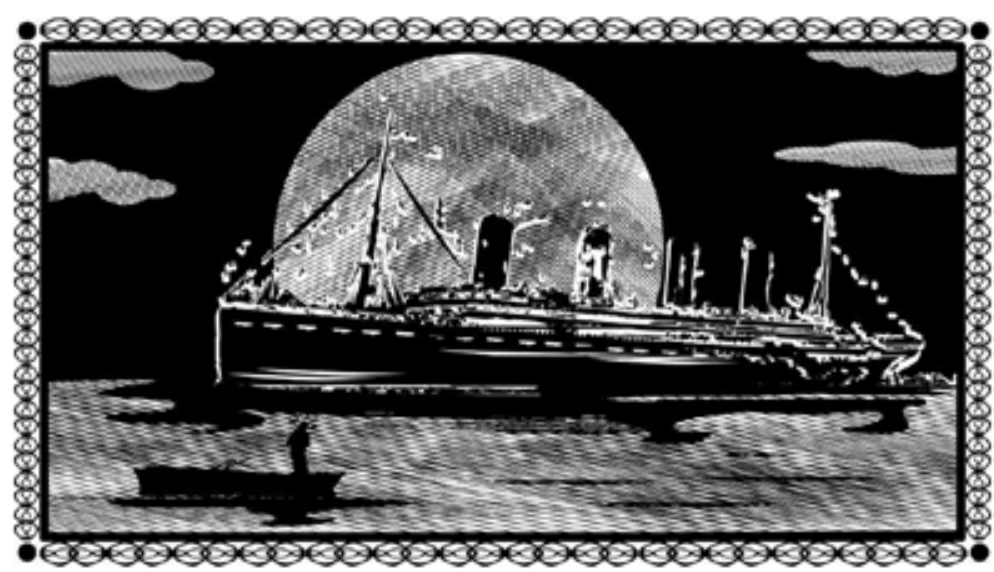

Fonte: elaboração própria

Havia na região do Formoso um jovem que gostava muito de namorar, mesmo vivendo com outra mulher em sua casa. Toda vez que ele ia encontrar uma moça, com a qual estava trocando chamegos, dizia para a sua esposa que ia ao comércio. Ele saía sempre entre seis e sete horas da noite, desviava o caminho e ia para onde estava a namorada. Em uma dessas viagens saiu por volta de sete horas da noite. Embora soubesse dos fenômenos sobrenaturais que aconteciam na região, não se importava, pois estava apaixonado e queria mesmo era namorar. Antes de embarcar em sua canoa para ir ao encontro da moça, que sempre o esperava em uma das ilhas, a Ilha das $\mathrm{Pa}-$ cas, ele avistou a uns 200 metros de distância, do outro lado do lago, uma pequena luz parecida como a de um palito de fósforo aceso. Ele não deu a menor importância.
Continuou sua viagem. A luz aparece para ele uma segunda vez, desta vez bem maior e mais perto. Ele ignorou, pois a vontade de encontrar a moça era maior que o medo. A luz sumia e depois voltava. Crescia e diminuía em sua direção. Então, ele parou de remar, pegou o facão e colocou ao seu lado. De repente, a luz criou velocidade de um foguete em sua direção e parou próximo da proa da canoa com faíscas coloridas. Agora, com muito medo, ele ficou parado, sem fazer qualquer movimento. Depois de alguns segundos a luz afastou-se da canoa, pegou rumo aos Aterrados, foi subindo até a altura das árvores e desapareceu. 0 jovem ficou parado por alguns minutos, sem entender o acontecimento. Ele não conseguia achar explicação. 0 medo tomou conta dele. Sentou-se no meio da canoa e voltou para sua casa remando o mais rápido 
que podia. Ao chegar à sua casa, não falou nada do acontecido. Deitou-se em uma rede. Tremia e gemia. A sua esposa e parentes ficaram preocupados achando que ele estava doente. Ele não falava nada. Somente no dia seguinte resolveu contar o que havia acontecido. Nunca mais o jovem saiu escondido para namorar.

Em várias entrevistas, a história da luz que aparece no lago para os moradores foi contada. Vejamos relato de "Seu" Euzébio: "Uma época passada... isso me dá até uma aflição de contar... eu ia muito pra casa de mamãe, que era na Tororoma. Quando a lua tava bonita era uma beleza, mas quando a lua tava escura, vinha uma luz que piscava no lago todinho. A luz aumentava e diminuía. Fazia como uma tocha. Essa luz aparecia para uma porção de gente. A pessoa ficava com medo. Eu fiquei com medo porque a tocha vinha bem pertinho de mim e corria quando eu tava dentro da canoa... Esse lago já teve muita encantaria. Hoje o cara grita, corre, dorme no lago. 0 povo antigamente não ia sozinho pro lago".

\subsubsection{História de um navio encantado}

Figura 9 - Representação da história de um navio encantado

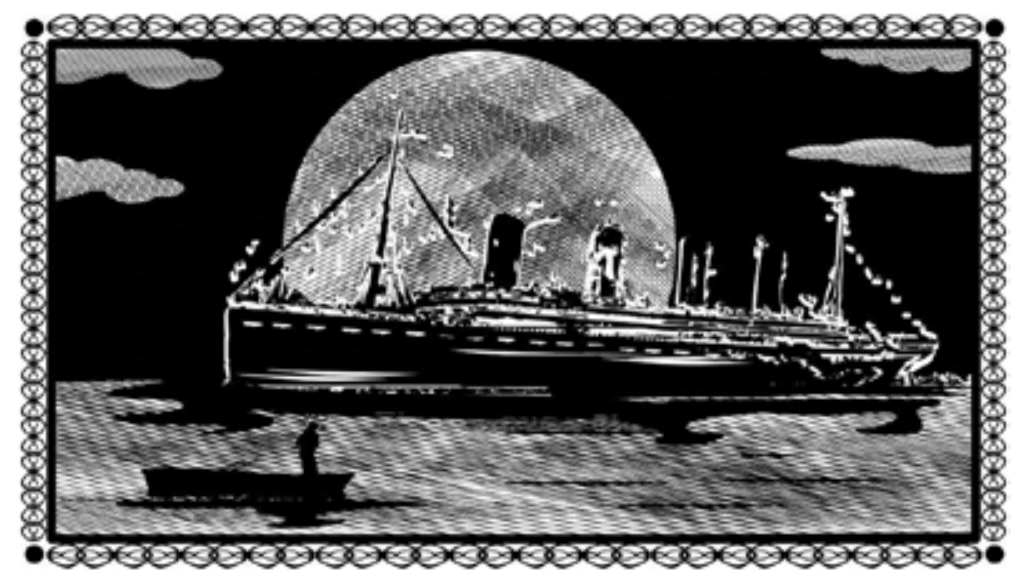

Fonte: elaboração própria

Contam que havia um cidadão conhecido pelo nome de Raimundo de Zuleide ou Índio. Índio morou algumas décadas na região do Formoso e presenciou vários acontecimentos - um deles foi uma grande visão que teve durante uma travessia noturna no Lago Formoso. A lua era linda, mas não estava muito clara. Índio embarcou em uma canoa emprestada de um amigo, saindo do porto da Tororoma para o porto do Jataí, que distam uns $3 \mathrm{~km}$. Depois de remar uma boa distância, de repente surgiu um grande navio no meio do lago. Ele foi parando de remar e firmou sua visão em direção daquela coisa nunca vista na sua vida e nem na vida de outras pessoas daquele lugar. Pra ele, o navio vinha em sua direção. Via os brilhos das luzes e isso lhe deixou um pouco desorientado, mas fascinado com que estava presenciando. Depois o grande navio foi se afastando dele lentamente sem fazer barulho algum. De repente, sentiu medo e tentou se livrar da visão. Começou a remar com toda força para alcançar o seu 
destino. Mas, seu esforço em remar rápido foi inútil, pois quando a canoa ancorou, Índio estava no mesmo porto que havia embarcado minutos antes. Com o medo, deixou para ir para o porto do Jataí só no dia seguinte quando amanheceu.

\subsubsection{Movimento das ilhas}

Existe na região o mito de que os Encantados movimentam as ilhas e, com isso, dizem se gostam ou não de algum visitante que chega ao Lago Formoso. Se uma das ilhas fecha a boca do canal de entrada para o lago, significa que os Encantados não querem que ele saia, ou querem que fique mais um pouco e quer dizer que gostam do visitante. Já se o visitante chega e uma das ilhas fecha a boca do canal antes da entrada da pessoa, significa que os Encantados não querem que a pessoa entre, não é bem vinda.

No entanto, há algumas hipóteses explicativas para o movimento das ilhas, mas que ainda devem ser estudadas em profundidade. As ilhas flutuantes começam a movimentar-se a partir do mês de março, de acordo com as cheias. 0 movimento no lago inicia pelo "balsedo" (amontoado de macrófitas aquáticas flutuantes), seguindose as pequenas ilhas; depois, as ilhas maiores vão se movimentando, segundo a ação de diferentes forças: i) o volume d'água, que dá força às correntes, conduzem as ilhas pelos $6 \mathrm{~km}$ de extensão do lago; ii) o vento, ajudado pela copa da vegetação local, que funciona como vela e cuja for- ça pode ultrapassar a das correntes d'água, mudando o curso das ilhas.

A crendice local credita aos Encantados do Lago Formoso total responsabilidade em relação ao movimento das ilhas. Por outro lado, a sabedoria local, extra-crença nos Encantados, acredita que uma terceira força, além das correntes e do vento, pode influir no movimento das ilhas: as raízes aquáticas que se movimentariam no sentido da absorção de nutrientes, conduzindo as ilhas para a parte do lago de recepção de águas, onde a concentração de nutrientes carreados é maior. É essa parte do lago, que recebe mais da metade das águas da bacia do Lago Formoso, que desperta maior curiosidade em relação ao movimento das ilhas, porque elas navegam contra a correnteza, descolando-se para o ponto de recepção da carga d'água, onde a força contrária é grande, ao invés de ficar nas partes das saídas das águas, deslocadas pela corrente.

"Seu" Euzébio fala do movimento das ilhas como obra dos Encantados:

\footnotetext{
“ Existiam muitos mistérios no lago. 0 vento tava pra cá e a ilha tava pra lá. A correnteza levava a ilha e ela vinha de volta sem correnteza, sem vento. Era coisa do Encantado. Mas, hoje o Formoso se acabou. 0 povo não respeita mais nada não.”

"Tinha uma ilha com dois Buriti que rodeava o lago e sempre voltava para o mesmo lugar.” (Dona Brasilina).
} 


\subsubsection{Mito do fojo}

Figura 10 - Representação do mito do fojo

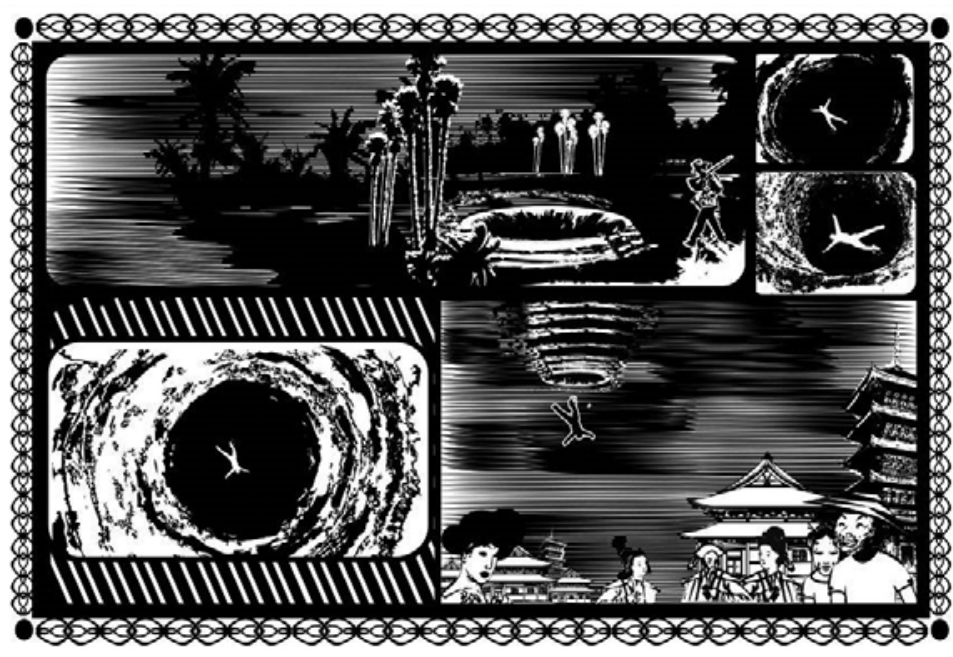

Fonte: elaboração própria

$\mathrm{Na}$ terminologia local, as falhas nos Aterrados são chamadas "fojos”. São grandes "poções", que segundo acredita-se localmente "são tão profundos que atravessam para o outro lado da Terra". "Se alguém cair nesse fojo pode até parar no Japão”.

Além dos mitos relatados acima algumas outras histórias foram citadas, mas não foi possível obter maiores explicações. São elas: a história de um cavalo todo de ouro com um cavaleiro que aparece para as pessoas, a história de um boi (de festas juninas) que aparece no meio do lago, a história de uma serpente gigante que vive no fundo do lago e a história de um forno cheio de dinheiro que está acorrentado no fundo do lago.

"Seu" Raimundo dos Santos conta que um morador da região encontrou um pedaço de um cano de ferro com algo de muito valor dentro. Não sabia se era ouro ou dinheiro. Esse morador, depois de encontrar o objeto, em uma semana se mudou do povoado. Afirmou que a pessoa que tira algo do lago tem que ir embora para longe porque senão morre.

\section{Narrativas orais sobre o passado e pre- sente dos recursos naturais}

Durante as entrevistas foi comum os moradores da região do lago Formoso destacarem fatos do passado e compará-los às mudanças observadas no presente, muitas das vezes em um clima de muita nostalgia. Ao falarem das mudanças ocorridas na pesca nos últimos dez anos, os moradores lembram o tempo da fartura de pescado:

"Olha, moça, percebi muita mudança aqui. De primeiro a gente com pouca rede panhava bastante peixe. Hoje com muita rede pega pouco peixe. De primeiro nóis tinha os aterradão e pegava muito peixe grande. Hoje em dia nóis tamo só no saldo. Hum! 0 Formoso aqui mudou demais... Os peixes vão embo- 
ra porque são peixes de sombra, aí não tem mais mato e os peixes não ficam. Eles estão devastando e o peixe não se cria mais.”

"Quando eu cheguei aqui esse lago era tudo rodeado de aterrado. Ai, foi destruindo, saiu a metade pro meio, outro tanto foi tocado fogo. Aí, o lago secou bastante, diminui o peixe. Não ficou mais beirada pro peixe se reproduzir, tá vendo?"

"Ah... aqui mudou muito. Tinha muito peixe, dona. Antes tinha mais peixe que consumidor. Em 1972, quando eu cheguei aqui...ah!dona, era muito peixe!” (Seu Euzébio).

“Antigamente era tudo mais fácil. Até o lago que não secava hoje seca. Os peixes eram maiores. Tinha mais aterrado. Quando não secava o lago parece que os peixes se criavam melhor. Agora tá se acabando tudo". (Dona Francisca Batista)

"O que mudou foi a diminuição do peixe por
causa da queima nos aterrados. Antigamen-
te para pegar peixe era ligeirinho. Hoje cus-
ta um pouco...Olha, o lago tá secando devido
às queimadas. Mudou muito...mudou o clima
do peixe. Mudou os aterrados porque já foi
destruído a metade pelo fogo....antigamente
era só mato. Hoje é tudo devastado. 0 lago
tá secando...Antes era um lago que não tinha
vara que topava no fundo. Hoje a gente em-
purra com o remo."

Nos relatos acima os narradores chamam atenção para a fartura que existia dos recursos e referem-se ao desperdício lancinante dos peixes e às queimadas na vegetação. Trazem na memória a abundância do passado e a escassez do presente.

Falam também da sobrevivência por meio da juçara, da preocupação com as mudanças e de como estão sendo devastados os recursos:

"Acho que a juçara diminuiu aqui mesmo por conta das queimadas. Tem vários aterrado acabado. 0 pessoal era pra tá comprando gado com o dinheiro da juçara. Vixe! Era uma beleza! Os pés botaram bem este ano, porque tem ano que a juçara não bota bem. Este ano a chuva vai ajudar. Quando chove ela fica boa logo. Se tivesse a juçara o tempo todo, dava pra viver. Só não vevi bem quem tivesse preguiça de molhar o pé. Dava pra nóis viver só da juçara e do peixe. Quando a juçara para é ruim até pros comércios. Fica tudo parado. No tempo da juçara vai movimentando tudo: vende a juçara, pega o dinheiro e paga o comércio".

"A juçara tá diminuindo devido às queimadas. Os agricultores, os donos de terrenos fazem a roçagem na beira do aterrado e não tem o cuidado de proteger o aterrado que acaba queimando. Antes o aterrado não era estragado de fogo. Hoje a metade do juçaral já foi destruído. Tem muita juçara no chão. Hum! 0 fogo já estragou demais!"

"Dona, o melhor ramo que tem aqui é o da juçara. Nóis fica feliz quando chega o tempo da juçara porque nesse tempo a gente ganha mais dinheiro. Dá até mais dinheiro que o peixe, e muito, minha amiga velha. Se ela fosse permanente dava pra viver. Se ela num falhasse, eu nem pescava" (Seu Euzébio).

“Dava pra viver só na juçara, com certeza! É um garimpo! 0 preço dela é bom. Nesse período de janeiro a abril dá até $\mathrm{R} \$ 20,00$ a lata”. (Domingos Gomes, pov. São Raimundo)

Narram os perigos encontrados nos Aterrados: 
"A juçara é só no aterrado. 0 aterrado é arriscado. Dona, a gente enfrenta cobra, caba, abelha, formiga, pico. A gente enfrenta mesmo porque tem precisão. Mas, não é fácil. $\mathrm{E}$ ainda tem o transporte que é ruim. Não é fácil!”. (Seu Euzébio)

"Ah! 0 solo é muito fofo. Tem a dificuldade grande por conta de a gente sair em cima de uma cobra, um cacho de maribondo, uma formiga... um dos maiores perigos é cair num fojo."

"Olha, moça, entrar num aterrado é perigoso. A gente vai, tira a juçara, mas não é bom não.” (Domingas Muniz).

Também narram sobre mudanças causadas pelo fogo nos Aterrados da região:

"Diminuiu muito! Não tenho nem dúvida. Agora com negócio de fogo acabou muito o aterrado. 0 pior é que aparece fogo nos aterrados e ninguém sabe nem quem bota."

Nos relatos percebe-se a preocupação com o meio ambiente e com o espaço onde vivem porque as modificações no meio implicam também em mudanças daquilo que os identifica. As relações entre o homem e seu meio são estreitas, como mostra parte de um relato:

"Os aterrados já foram muito destruído pelo fogo. Nóis tamo aqui pelejando com o que sobrou pra não queimar mais. Porque é nossa vida, né?"

0 desrespeito ao meio ambiente pode assolar o modo de vida das comunidades e gerar mudança no seu cotidiano, no seu modus vivendi.
"Dona, antigamente, nóis aqui até vivia bem. Dava pra plantar porque tinha muita mata. Mas, hoje não tem mais terra boa. Tão devastando tudo. Só tem capim. Tem ano que é muito ruim de roça. Aí, nóis vai procurando outros meio pra sobreviver. E disso tudo o causador é o próprio homem que não respeita mais nada."

Numa visão hermenêutica, todas as narrativas orais nos remetem à relação entre homem e natureza, strictu sensu, bem como no sentido cultural. Os encantos e mistérios da região constituem os elementos das narrativas orais, que construíam valores e regras que eram respeitadas e, dessa forma, transmitiam ensinamentos morais.

Mesmo sem adentrarmos em uma análise interpretativa mais profunda, percebemos que as histórias narradas evidenciam o respeito que existiu no passado à natureza, mesmo que por um temor do sobrenatural, e o uso descuidado da natureza nos dias atuais.

Esta parte da pesquisa mostrou que a crença em entidades sobrenaturais, como os Encantados, por muitos manteve certo estado de conservação da natureza na região do Lago Formoso. Hoje, temor e respeito às entidades protetoras do Lago e Aterrados, perdem sua influência; fato que pôde ser constatado em conversas informais com moradores mais jovens. No imaginário local a signifıcação simbólica de fenômenos, aparentemente inexplicáveis, se mistura à descrença e à busca na natureza por tudo o que ela ainda pode oferecer.

As sociedades contemporâneas, mesmo que em lugares distantes e de difícil acesso, têm seus comportamentos sitiados por apelos de cunho mercantil que têm sobrepujado as culturas das populações tradicionais. Apesar disto os mitos sobrevivem. As entidades mitológicas que povoam o Lago e seus Aterra- 
dos continuarão vivas nos contos orais, pois perduram por gerações, embora não mostrem mais ter o poder de moldar o comportamento dos homens no que diz respeito à conservação dos recursos naturais da região.

A crença nos seres sobrenaturais, por muito tempo, contribuiu para a conservação dos Aterrados. No entanto, hoje o simbolismo dos contos orais tem sua função de guiar o comportamento dos indivíduos diminuída. Atualmente, a quase completa ausência de crença nos Encantados e as necessidades econômicas, implicam em grandes danos ambientais, provocados, principalmente pelas queimadas e desmatamentos na região do Lago Formoso.

\section{0 desaparecimento dos mitos: perda cul- tural x perda ambiental}

Na região do Formoso, a descrença nos mitos ocorre paralelamente à destruição ambiental. Está compelida pela necessidade de produção econômica. À medida que diminuem as matas de Aterrados vão se perdendo também os antigos mitos sobre os Encantados.

Alguns mitos levantados mostram que havia uma relação entre homem-natureza interdependentes que implicavam em respeito ao meio ambiente, em especial às ilhas flutuantes e aos seus Encantados, além de acarretar em ensinamentos morais. $\mathrm{Na}$ história da ilha que causou a morte de um morador, por exemplo, os xingamentos contrariaram regras morais dos moradores da região. Em duas narrativas contadas, xingar implicou em castigos ao protagonista da história.

Em muitos mitos da região amazônica, pedir permissão e ter responsabilidade são o suficiente para utilizar os recursos. Mas também, a astúcia, malícia e dissimulação do personagem também podem ser o suficiente para que este sofra algum castigo. No mito sobre a história da tarrafa que foi cortada, também é narrado a necessidade de se ofertar aos Encantados fumo ou bebida alcoólica. A despeito disto Levi-Strauss (1985, p. 55) diz que o tabaco é o meio de comunicação com o mundo sobrenatural e que é utilizado para evocar os espíritos, correspondendo a uma manifestação da cultura de alguns povos no seio da natureza.

$\mathrm{Na}$ história do pescador de traíra, mais uma vez a figura mítica dos Encantados é ressaltada. Pedir licença ao entrar em um Aterrado é fundamental para que nada de ruim aconteça e para que haja sucesso na atividade a ser realizada pelo morador daquela região.

No entanto, o que se observa hoje na região é a perda da crença nos mitos que, outrora, se configuravam como uma estratégia de conservação na natureza como mostram os relatos abaixo:

"Eu acho que quando as pessoas tinham medo dos mistérios, os Aterrados eram mais protegidos. 0 povo não invadia ao Deus dará. Antigamente era mais respeitado.” (Seu Raimundo).

"Eu me lembro das coisas que aconteciam no lago... Para atravessar para a Tororoma ia todo mundo em silêncio. Se olhasse algo na beira do lago não tinha que perguntar o que era. Tinha muito bicho também. Tinha lontra de bando que derrubava a canoa. Ninguém podia fazer barulho." (Dona Brasilina).

"Era bom se o povo continuasse acreditando nos Encantados. Porque aí o povo respeitava mais. Hoje ninguém tem nem consideração com gente, quanto mais com coisa assim de Aterrado." (Dona Benedita da Paz). 
"Tem gente que diz que olhava pessoas saindo e entrando em uma ilha que flutuava. Às vezes, escutavam também batucada de tambor nessa ilha, mas ninguém nunca sabia quem era. Fazia medo e a gente não saía sozinho à noite pra ir pro lago. Tinha vez que não podia ir nem no poço tomar sozinho. Mas, hoje não tem mais isso não. Neguinho não tá mais nem aí pra essas coisas." (Dona Benedita).

"Seria bom se as pessoas continuassem acreditando nos Encantados porque aí não faziam tanta coisa ruim dentro dos Aterrados". (Seu Euzébio).

“Antigamente o povo respeitava. Hoje não respeita mais não. Eles querem é acabar com o que tem. Se não fosse "Seu" Galdino (agricultor da região e ambientalista) as coisas estavam pior por aqui." (Nenezinha).

As mudanças culturais e as transformações ambientais fazem parte de um mesmo processo: conforme as matas vão diminuindo, o lago vai secando, a quantidade de peixes vai sendo reduzida, o modo de vida das comunidades da área de estudo se modifica e a sua visão cultural é alterada.

Antes os Aterrados não "pertenciam" aos moradores da região. "Pertenciam" aos Encantados, portanto não podiam usá-los indiscriminadamente. Para entrar em um Aterrado e extrair algo dele era preciso pedir licença, e o que era dado ao homem era como um favor que devia ser recompensado com alguma oferenda, e assim os Encantados cuidavam dos Aterrados.

0 que se destaca nos mitos levantados é uma perspectiva ambiental proveniente de um conjunto de condutas do homem, que sustentava uma forma de uso dos recursos naturais adequados à capacidade do ecossistema local em suprir as necessidades das comunidades.
Durand (2005) coloca que em alguns grupos que têm ou tiveram uma relação equilibrada com o entorno, os mitos têm um papel muito importante. A morte dos mitos e de seus deuses estão entre as causas que promovem a destruição ecológica.

Na região do Formoso, a destruição ambiental está relacionada, entre outros fatores, às mudanças culturais das comunidades que estão se integrando às atuais dinâmicas econômicas e sociais. 0 aumento populacional, por exemplo, implica na ocupação de novas terras para moradia, plantação e criação de gado. A maior demanda por produtos extraídos dos Aterrados, como a juçara, acarreta uma maior exploração daqueles ambientes. Os fatores que explicam as mudanças na dinâmica cultural e sobre o uso dos recursos naturais são internos e externos às comunidades da região.

Esta pesquisa mostrou como tempo, respeito e temor ao sobrenatural foi sendo substituído por importantes necessidades como a subsistência alimentar da crescente população e a comercialização de produtos locais. Embora, atualmente, as condições das estradas vicinais da região do Formoso não sejam boas, é possível o transporte e venda de produtos comercializáveis (ex. juçara e coco babaçu). Os moradores necessitavam de uma forma de trabalho que lhes gerasse renda, e a economia voltada para o autoconsumo foi complementada com a expansão da economia para fora da região do Formoso e de Penalva.

A diminuição de boas terras para agricultura, as enfermidades que atacam os animais, as pragas que destroem os plantios, a diminuição na quantidade de peixes no lago e a dificuldade de transporte e comercialização do pescado para fora da região do Formoso, são algumas das razões atribuídas pelos moradores para exploração da juça- 
ra - esta que, segundo a população local, é a atividade através da qual suas condições socioeconômicas e de vida são melhoradas. Embora, contraditoriamente, aquele tipo de vegetação venha sendo destruída.

É difícil saber qual processo se iniciou primeiro: se foi a perda da crença nos mitos relacionados aos Encantados ou se foi a degradação do meio ambiente. 0 mais provável é que os dois processos venham acontecendo simultaneamente.

Nesse sentido, cabem aqui alguns questionamentos: É possivel conservar os Aterrados sem os mitos? A conservação desses ambientes existe se usarmos somente o discurso do desenvolvimento sustentável, da valoração econômica e da educação ambiental?

Entre os esforços para a conservação da natureza está o desafio de transformá-la ou mantê-la como um elemento de identidade, de respeito e de sensação de pertencimento. São esses ensinamentos que os mitos dos Encantados querem repassar.

\section{Considerações finais}

Os mitos levantados relacionados aos Encantados (considerados como entidades protetoras daquela vegetação) simbolizam, em sua maioria, o respeito que existia a estes espíritos e aos fenômenos sobrenaturais, produto de punição ou lição como ensinamento. A obediência ora existente pelo sentimento de medo ou mesmo de reverência, e a crença que implicava em uso controlado dos recursos da natureza, vêm perdendo influência no comportamento dos indivíduos e, consequentemente, acarreta em prática de uso descuidado empregada habitualmente pela população local.

Os grupos humanos que mantêm relatos populares de tipo tradicional, por meio da oralidade e que estão nos dias de hoje em contato crescente com os padrões culturais que difunde a televisão, embora bastante longe das melhores tecnologias da informática e seus efeitos globalizadores, terminam influenciados, sofrem uma mudança social que afeta os valores culturais da região.

Mesmo com a atividade narrativa atualmente debilitada, é incontestável que durante muito tempo serviu como meio de entretenimento de muitas pessoas, inclusive dos mais velhos, mas também de aprendizagem de saberes e de sensivel forma de coesão social.

Nesse sentido, o que se percebe é que alguns moradores das comunidades de entorno do lago Formoso experimentam um progresso material (televisão, antena parabólica, celular) que lhes proporciona certo bem estar. 0 sentido de sua residência no lugar, de pertencimento a um grupo e o recíproco reconhecimento como vizinhos perdeu boa parte de sua especificidade. As reuniões e conversas ao fim do dia são substituídas pelas novelas e notícias da televisão, por músicas e conversas nos celulares e por outras distrações que não a narração dos contos e mitos.

Este parece ser um fenômeno recente e ambíguo. Ambíguo porque, por um lado, integra as vantagens associadas ao "desenvolvimento" ou progresso e, por outro, a perda de um patrimônio cultural no qual se fundamentava o sentido de toda sua singularidade. Percebe-se essa perda com aflição, pois a modernização vivida pela população local altera profundamente, em pouco tempo, uma cultura excêntrica e o comportamento do homem com relação à natureza. Assim, a transformação cultural que gravita na região do Formoso sobre sua tradição, reduz o potencial orientador dos mitos e oculta sua exemplaridade.

Ficou claro, nesta parte da pesquisa, que a eficiência dos antigos valores re- 
presentados nos mitos (que quando cridos orientam o comportamento humano e contribuem para uma harmoniosa relação da sociedade com a natureza) é acometida pela diminuição na crença aos Encantados, em consequência de novos valores e costumes incorporados nas comunidades. Essa depreciação cultural concorre para a ausência de atitudes conservacionista da natureza. As ações humanas, agora mais individualistas, e as interações sociais orientadas por valores culturais, aparentemente estão aos poucos se perdendo.

Estar em contato com os espíritos e temer o miraculoso significava uma capacidade de atuar para manter o equilíbrio na natureza. A forma de se comportar com relação à natureza e com as pessoas estava, como mostram os mitos, fundamentada em uma moral que mantinha as relações em condições de estabilidade e evitava os castigos pelas forças sobrenaturais - castigos estes concretizados em visões, sons, sensações estranhas e em acontecimentos reais de caráter extraordinário.

Apesar da fragilidade desse patrimônio cultural, os mitos e as lendas sobre Encantados permanecerão na memória viva daqueles que narraram, daqueles que ouviram e daqueles que acreditaram e/ou acreditaram nos espíritos guardiões do Formoso. Essa cultura prosseguirá existindo na sabedoria moral acumulada, na sabedoria dos mais velhos, conhecida e respeitada por suas experiências, pois embora os mitos tenham caráter fictício, não quer dizer que estejam desligados da experiência real dos narradores.

\section{Referências}

AMOROZO, M. C. M; MING, L. C.; Da SILVA, S. P. Métodos de coleta e análise de dados em etnobiologia, etnoecologia e disciplinas correlatas. Rio Claro: UNESP;SBEE; CNPq, 2002.

BARTHES, R. Mitologías. 3. ed. Madrid: Siglo XXI, 2000.

DIEGUES, A. C. S. 0 Mito moderno da natureza intocada. São Paulo: Nupaub; USP; CEC, 2008.

DURAND, G. As estruturas antropológicas do imaginário. Introdução à arquetipiologia geral. São Paulo: Martins Fontes, 2001.

GEERTZ, C. La interpretación de las culturas. Barcelona: Gedisa, 2005.

GUAL, C. G. et al. Mitos. 1. ed. Madrid: Siruela, 1998.

HAWLEY, A. Ecology and Human Ecology. Social Forces, v. 22 (4): p. 398-405, 1944.

WHITE, L. A. The concept of culture. American Anthropologist, v.61, (2): p. 227-251,1959.

LÉVI-STRAUSS, C. Palabra dada. Madrid: EspasaCalpe, 1984.

MERCANTE, M. S. Os mitos e a relação cultura x meio ambiente. 2011. Disponível em: <http:// www.cfh.ufsc.br/imprimat/artigos/mitos.htm>. Acesso em: 4 maio 2011.

PEREIRA, B. E. ; DIEGUES, A. C. Conhecimento de populações tradicionais como possibilidade de conservação da natureza: uma reflexão sobre a perspectiva da etnoconservação. Desenvolvimento e Meio Ambiente, $n^{\circ}$ 22, p. 37-50, jul./dez. 2010.

RAPPAPORT, R. A. Naturaleza, cultura y antroplogía ecológica. In: SHAPIRO, H. (Ed.) Hombre, cultura y sociedad. México: Fondo de Cultura Económica, 1985. p.261-292.

ROCHA, E. 0 que é mito. Coleção Primeiros Passos, São Paulo: Brasiliense, 1985. 
RESUMO

$\mathrm{Na}$ região da Baixada Maranhense, na Amazônia Legal Brasileira, mais particularmente no município de Penalva, os Aterrados são parte importante da paisagem, constituindo ambientes peculiares desta região. Esta pesquisa teve como objetivo principal levantar e analisar a cultura local relacionada às crenças em entidades encantadas que protegem os Aterrados, e as consequências da perda ou manutenção dessa cultura em relação à conservação desses ambientes. A conclusão é de que a conservação dos Aterrados é fundamental para o sustento continuado das populações locais que mantêm suas atividades produtivas e de subsistência com produtos extraídos desses ambientes. A integração das comunidades às dinâmicas econômicas atuais é um dos fatores que contribuem para a degradação do meio ambiente e perda cultural.

\section{PALAVRAS CHAVE}

Mitos. Aterrados Encantados. Lago Formoso. Baixada Maranhense.

\section{ABSTRACT}

In the region of Baixada Maranhense, in the Brazilian Amazon, more particularly in the municipality of Penalva, Aterrados are the important part of the landscape, providing unique environments of this region. This research aimed to survey and analyze the local culture related to beliefs in entities thrilled that protect this Aterrados and consequences of the loss or maintenance of this culture in relation to the conservation of these environments. The conclusion is that the conservation of Aterrados is critical for continued local populations that maintain their production and livelihood activities with products taken from these environments support. The integration of communities to current economic dynamics is one of the factors that contribute to the degradation of the environment and cultural loss.

\section{KEYWORDS}

Myths. Aterrados. Delighted. Lake Formoso. Baixada Maranhense. 
